
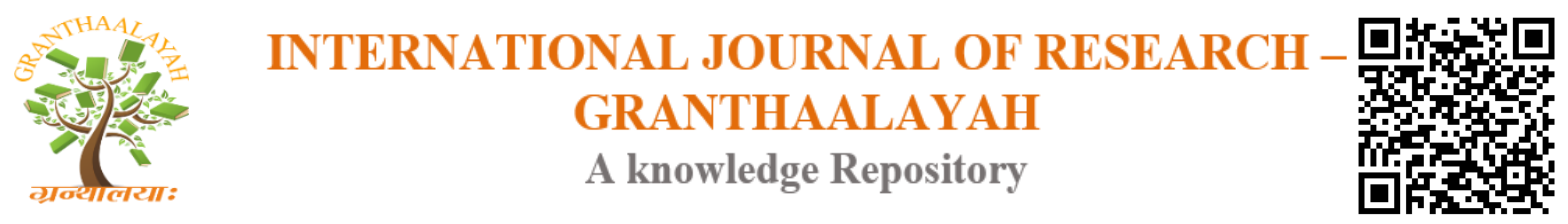

Management

\title{
SUSTAINABILITY ECONOMIC AND ECONOMIC GROWTH: THE MODERATING EFFECT OF DISPARITY REGION AND INCOME ON SOCIETY WELFARE
}

\author{
Sjamsul Arief ${ }^{1}$, Ujianto ${ }^{2}$, Djohan Mashudi ${ }^{3}$ \\ ${ }^{1}$ Student of Studies Doctoral Programe Post Graduate Program of Economics and Business 17 \\ Agustus 1945 University, Surabaya, Indonesia \\ ${ }^{2}$ A Professor for the Economics Faculty of 17 Agustus 1945 University Surabaya, Indonesia \\ ${ }^{3}$ A Professor for the Economis Faculty of Pembangunan Nasional University, Surabaya \\ Indonesia
}

\begin{abstract}
This study aims to examine and analyze the influence of regional financial independence, capital expenditure, government investment with moderate effects of disparity between regions and income disparities to economic growth, employment and community welfare. Data analysis method used was Structural Equation Modeling (SEM) with Partial Least Square (PLS) approach, to test the ten hypotheses formulated in this research, then used path analysis (Path Analysis).

The conclusions of this study are: (1) Regional financial independence has a positive and significant impact on economic growth, while regional financial independence with moderate effects of disparity between regions has a negative but not significant effect on economic growth. (2) Regional financial independence has a positive and insignificant effect on labor absorption, while regional financial independence with moderate effects of disparity between regions has positive and insignificant effect. (3) Regional financial independence has a positive and significant impact on the welfare of the community. (4) Local government capital expenditure has negative and insignificant effect on economic growth, while regional government capital expenditure with moderate effect of disparity between regions has positive and insignificant effect on economic growth. (5) Local government capital expenditure has negative and insignificant effect on labor absorption, while regional government capital expenditure with moderate effect of disparity between regions has positive and insignificant effect on labor absorption. (6) Local government investment has negative and insignificant effect on economic growth, while local government investment with moderate effect of inter-regional disparity has positive effect not significant to economic growth. (7) Local government investment has a positive and significant effect on labor absorption, while local government investment with moderate effect of disparity between regions has negative and insignificant effect on labor absorption. (8) Economic growth has a positive and significant impact on the welfare of the community, while the economic growth with the effect of moderation income disparity has a positive but insignificant effect on people's welfare. (9) Employment absorption has a negative and significant effect on people's welfare, while employment absorption with moderation effect of income disparity has negative and insignificant effect on people's welfare. (10) Local government investment has a positive and insignificant effect
\end{abstract}


on people's welfare. Increased local government investment spending does not provide much improvement in the welfare of the people.

Keywords: Regional Financial Independence; Capital Expenditure; Government Investment; Economic Growth; Labor Absorption and Disparity.

Cite This Article: Sjamsul Arief, Ujianto, and Djohan Mashudi. (2018). "SUSTAINABILITY ECONOMIC AND ECONOMIC GROWTH: THE MODERATING EFFECT OF DISPARITY REGION AND INCOME ON SOCIETY WELFARE." International Journal of Research - Granthaalayah, 6(5), 300-320. https://doi.org/10.29121/granthaalayah.v6.i5.2018.1453.

\section{Introduction}

Economic development undertaken by a country aims to improve the standard of living, welfare and the dignity of the people, which includes improvements in basic goods, living standards and the expansion of economic and social choices for all societies (Todaro and Smith, 2006). In terms of economic development objectives, the government sets economic policies for improving the welfare of communities supported by increased employment and poverty reduction. In addition, economic development was also one of the efforts to accelerate the pace of economic growth that also able to encourage the performance of other economic sectors more efficiently, effectively and productively.

High economic growth will be able to create greater income distribution and improve the welfare of the people, and if accompanied by efficient and effective resource allocation, it will be a stimulus in development, especially in developing countries. The multiplier effect of economic growth will drive other sectors of the economy in the future economy (Todaro, 2000: 132). Therefore, economic growth becomes one of the important indicators to analyze the economic development that occurs in a country.

A country's economic development was successful if economic growth was accompanied by a decrease in income inequality. Todaro (2004) states that income inequality has a positive and negative side to economic policy in a region, which in one side will encourage less developed areas to compete and increase its growth in order to improve its welfare, while the negative side if the extreme inequality will result in economic inefficiency, undermines social stability and solidarity which was often seen as an injustice of the welfare of society.

Inequality of income between regions can be caused by differences in demographic conditions. According to Syafrizal (1997), demographic conditions include differences in the rate of growth and structure of the population, the different levels of education and health of the local people concerned, will affect the productivity of community work in the region. Good demographic conditions tend to increase work productivity, so as will increase economic growth of a region.

Statistics Central Bureau (BPS) report that Indonesia's economic growth in 2017 was 5.07 percent. Spatially the structure of the Indonesian economy was still dominated by provincial groups in Java Island. Java's contribution to the Indonesian economy reached 58.49 percent. Then, followed by Sumatra by 21.66 percent, Kalimantan 8.20 percent, and Sulawesi 6.11 percent. The remaining 
5.54 percent are on the other islands. BPS data said the contribution of Bali and Nusa Tenggara to the national economic growth was 3.11 percent. Papua's contribution was 2.43 percent.

East Java as one of the provinces in Java has an economic growth of 5.45\% in 2017. East Java Province's long term development plan was set in the East Java Provincial Long Term Development Plan (RPJD) for 2005-2025. There are six long-term development mission of East Java Province, namely: (1) develop modern economy of East Java based on agro; (2) to realize a reliable human resources, have a noble and cultured character; (3) realize the ease of access to improve the quality of life; (4) optimizing the utilization of natural and artificial resources; (5) developing high value added infrastructure; (6) developing good governance.

Implementation of the first long-term development mission was to develop the modern economy of East Java based on agro seen from the total investment in the field of fertilizer that has the greatest investment value of Rp. 8.8 trillion of the total value of investment during the period January to June 2010 which recorded at Rp. 35.39 trillion. In addition to fertilizer, the value of investment in other fields of cement was Rp. 4.86 trillion, basic chemical field of Rp. 4.6 trillion, and cigarettes reached Rp. 3.83 trillion. Although the investment value in East Java was quite large, there are still some problems that hinder the entry of investors, such as lack of electricity, gas, poor infrastructure in some places, difficult land acquisition and slow licensing process in some Regency (Provincial Investment Board East Java, 2010).

Investment from several business sectors above has contributed a fairly high economic growth rate in East Java which was $6.18 \%$ above the national average. While the realization of domestic investment, East Java including the largest and ranked first nation with an investment of Rp. 5.1 trillion, followed by East Kalimantan, West Java and Riau (Investment Board of East Java Province, 2010). Total capital expenditures of regency / municipal governments in East Java Province increased from 2011 to 2014 amounting to Rp. 6.246.251 million in 2011, Rp.8.628.366 million in 2012, Rp. 9.970.563 million in 2013, and Rp.12.744.911 million in 2014. While in 2015 decreased to Rp. 6.880 .039 million.

The average investment of regency / city government in East Java Province in 2011 was relatively high at almost 6 times from the previous year (2010) of 593.88 percent, then in 2012 decreased by 41.74 percent, and then up again in 2013 by 162.04 percent. Then in 2014 experienced a very sharp decline of 74.66 percent, and in 2015 slightly increased by 7.82 percent. While the average economic growth in Regency / cities in East Java Province in 2011 until 2015 decreased, except in 2012 and 2015, it increased but in relatively small number.

Rapid economic growth and not balanced with equity will lead to regional disparity (regional disparity). Basri (1995: 92) states that there are several kinds of gaps that often block a society in the effort to achieve prosperity, namely: (1) the gap between regions, (2) the gap between sectors, and (3) the society income distribution gap. Gap between regions seen with the existence of a developed region with an underdeveloped region. Economic development of a region was said succeed if it can increase economic growth and welfare of people in the area evenly that better known as the Human Development Index (HDI). The welfare and economic prosperity in a country can be realized in the modern economy through the role of government in three classes, namely: (1) the role of allocation; (2) the role of distribution, and (3) the role of stabilization. Human 
Development Index (HDI) was based on three ends or end products of development, namely: life span (longevity) as measured by life expectancy, then knowledge (knowledge) as measured by adult literacy skills (two-thirds) and average school year (one-third), and standard of living as measured by real income per capita. HDI rates all countries into three groups of human development levels, namely: (1) the lowest level of human development (0.00 to 0.499), (2) the middle rate of human development (0.50 to 0.799$)$, and (3) high human development (0.80 to $1.00)$.

Human Development Index (HDI) of East Java province during the period of 2011 until the year 2015 was at the level of middle human development that was between the value of 0.50 to 0.799 . Development in the spatial sphere was not always equitable, the inequality of income between regions becomes one of the serious problems. Research of Denni Sulistio Mirza (2012) mentions that economic growth has a positive and significant impact on human development index. The economic growth that has been achieved was not able to overcome the problems that arise due to uneven development because there are also some areas experiencing rapid economic growth, but some other areas experiencing slow economic growth.

Much research on development economics have been done by experts, from poverty, economic growth, investment, capital spending and employment; but the analysis discussed revolves around the direct relationship or influence between latent variables, whereas this study has differences with the previous research that includes disparity variables between regions and income disparity as moderating variables into the analysis of direct relationship between latent variables. Indeed there are previous researchers who include income disparity variables as intervening variables. The reason for this research was to make variables of disparity between regions and income as moderating variables because disparity was a disease that will weaken or strengthen efforts to improve the welfare of the community through independent financial region, capital expenditure, government investment that can affect economic growth and employment.

According to Solow - Swan (Arsyad, 2010: 88) theory, economic growth depends on the development of production factors such as the rate of capital growth, the rate of population growth, and the rate of technological growth. The growing investment climate in the field of healthy and competitive production factors will spur the development of mutually beneficial investment in regional development. The results of Ram's (1986) and Baffes (1998) studies conclude that private investment has a positive and significant impact on economic growth, as investment accumulates capital, by building a number of useful buildings and equipment, a nation's potential output increases and long-term economic growth increased. Through investment, the government can create economic opportunities by providing business opportunities and community empowerment by encouraging the absorption of potential and public funds in infrastructure development in the area such as markets and in turn can improve the welfare of the community.

\section{Theoretical Background and Hypotheses}

Economic development was generally defined as a process that causes per capita income of a country's population to increase over the long term that accompanied by the improvement of the institutional system. Arsyad, (2010: 11) explains that economic development has four important properties, namely (1) a continuous process of change; (2) efforts to increase per capita income; 
(3) increment of per capita income must continue in the long run, and (4) improvement of institutional system in all fields, such as economics, politics, law, social and culture. Increased income per capita points to improvements in the economic welfare of the people, and usually the rate of economic development of a country was indicated by the rate of increase in Gross Domestic Product (GDP) or Gross National Product (GNP).

Development process was basically not just a mere economic phenomenon. Development was not merely demonstrated by the achievements of economic growth achieved by a country, but more than that, development has a broad perspective. The often neglected social dimension in the approach of economic growth, it gets a strategic place for the development process. In the development process, in addition to considering the aspects of growth and equity, it also consider the impact of economic activity in the social life of the community. Moreover, in the process of development, efforts are made to aim to change the structure of the economy towards the better (Kuncoro, 2003: 45).

Development must reflect the total change of a society or the adjustment of the social system as a whole, without neglecting the diversity of the basic needs and the desire of the individual and the social groups within it to move forward toward a better, material and spiritual state of life (Todaro 2004 : 21). Regional economic development was a process, which was a process that includes the establishment of new institutions, the development of alternative industries, the improvement of existing manpower capacity to produce better products and services, identify new markets, transfer knowledge and development of new companies. According to Arsyad, (2004: 108) Regional economic development was a process whereby local governments and communities manage existing resources and form a partnership pattern between the government and the private sector to create new jobs and stimulate the development of economic activities (economic growth) within the region.

The main problem in regional development lies in the emphasis on development policies based on the endogenous nature of the region by using the potential of institutional resource and local physical resource. Law No. 32 of 2004 on Government Regions, formed based on consideration of economic capacity, regional potential, socio-cultural, socio-political, population, area, and other considerations that enable the implementation of Regional Autonomy. The main features that indicate a region was capable of implementing autonomy: (1) The ability of regional finances, meaning that regions must have the authority and ability to extract financial resources, manage and use their own finances sufficient to finance the administration. (2) Dependence on Central Government funds should be minimal, so that PAD can be part of the largest financial resources supported by central and regional fiscal policy so that the role of local government becomes larger (Abdul Halim, 2001: 167).

In order to strengthen local finance one of them was fiscal decentralization which was the delegation of authority from the central government to take decisions and fiscal management to the local government. According to Boex, (2001: 14) Fiscal decentralization consists of four pillars, namely: (1) spending, regulating the functions and responsibilities of spending for each level of government; (2) revenues, with respect to the sources of tax or non-tax revenue received by the regional government; (3) transfers, with regard to revenues from the central government; and (4) financing, as a counterweight between regional income and expenditure, see figure 1. 


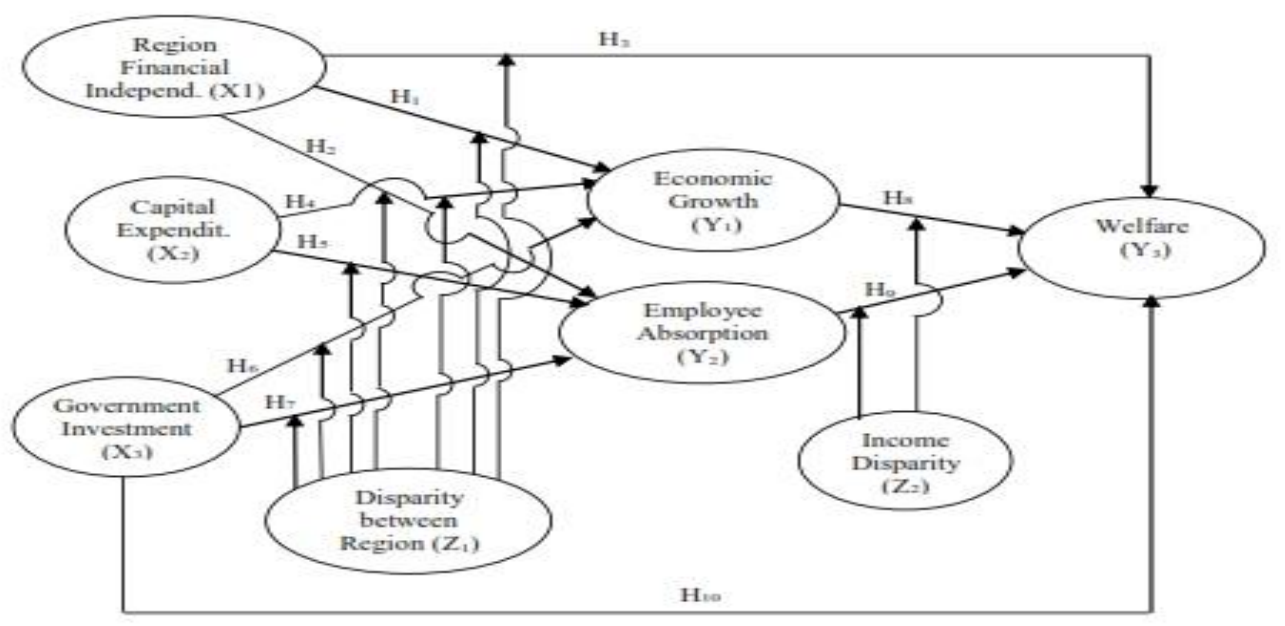

\subsection{Hypothesis}

Based on the background of the problem, literature review, and conceptual framework of research, the hypothesis was proposed as follows:

H1: The higher level of Regional Financial Independence and with the prevalence of disparity between regions, the higher the economic growth in East Java Province.

H2: The higher level of regional financial independence and with the prevalence of disparity between regions, the higher the employment in the Regency of East Java Province.

H3: The Regional Financial Independence significantly affect the welfare of the community in the Regency of East Java Province.

H4: The higher Capital Expenditures of Local Government and with the prevalence of disparity between regions, the higher economic growth in Regency of East Java Province.

H5: The higher Capital Expenditures of Local Government and with the prevalence of disparity between regions, the higher the employment in the Regency of East Java Province.

H6: The higher Investment of Local Government and with the prevalence of disparity between regions, the higher economic growth in Regency of East Java Province.

H7: The higher Investment of Local Government and with the prevalence of disparity between regions, the higher the absorption of manpower in Regency/City of East Java Province.

H8: The higher economic growth and with the prevalence of income disparity, the higher the welfare of the people in the Regency/City of East Java Province?

H9: The higher absorption of manpower and with the prevalence of income disparity, the higher the Welfare of the Community in the Regency / City of East Java Province.

H10: Local Government Investment significantly affects the welfare of the community in Regency/City of East Java Province?

\section{Methods}

The unit of analysis in this study was all Regency / municipalities located in the province of East Java in the form of census. The choosing of this province with the consideration that East Java in addition was the second largest province in Indonesia was also a province with the largest number of Regency / cities consisting of 29 Regency and 8 cities (BPS, 2012). The data used are time series data from 2006 to 2015 and cross section data consisting of 38 Regency / cities in East Java 
Province so that it was a pooled data, that was combination of time series data with cross section data.

The variables used in the analysis of research data include (1) independent variables namely the variable of regional autonomy, capital expenditure and government investment; (2) Moderate variables are Inter-regional Disparity variable and income disparity; (3) Dependent variable namely variable of Economic growth, Employment Absorption and Social Welfare.

Ratio of Regional Financial Independence (RKKD), calculated by comparing the amount of revenue of Regional Real Income divided by the amount of transfer revenue from the central / provincial government as well as the regional loan, (Mahmudi, 2010: 142).

Capital Expenditure, was the realization capital expenditure used by local governments for the acquisition of fixed assets and other assets that provide benefits over one accounting period (Statement of Governmental Accounting Standard No.2). Government Capital Expenditure was expressed in rupiah value at constant (real) price.

Government Investment, was a fund issued by the government as capital participation that was used to fund activities related to the time dimension that longer than one budget year, such as equity participation in State-Owned Enterprises (BUMN) or Regional-Owned Enterprises (BUMD).

Economic Growth, was a change of Gross Regional Domestic Product (GDP) per year by constant prices expressed in units of percent. The formula for calculating economic growth (Y1) is:

$$
\mathrm{Gt}=\frac{P D R B T t-P D R B t_{-1}}{P D R B t_{-1}} \times 100 \%
$$

Where:

Gt : : is economic growth per year.

PDRBt: $\quad$ is the GRDP of the current year

PDRBt-1: is the GRDP of the previous year

Absorption of manpower, was the number or number of people working in all economic sectors measured in terms of people (BPS, 2009: 60). Economic disparities between regions, (disparity) was a condition seen from various differences in welfare and economic development among regions. Measured using the Williamson index formula.

Welfare Society, was related to the amount of goods and services available and can be consumed by the community. To measure this welfare, Human Development Index (HDI) based on economic, health and education measurement was used. Data analysis used in this research was Partial Least Square (PLS). According to Tobias in Widjanarko (2009), PLS was a soft modeling method, which can simultaneously perform testing the measurement models as well as testing the structural models. The structural model was used for causality testing. 


\section{Analysis and Results}

In this study the data used are macroeconomic secondary data from 29 Regency and 9 cities in East Java. The data used comes from several agencies such as the Central Bureau of Statistics and the Ministry of Finance consisting of several years of publication. The results of the data gives the description as follows:

Investment can be described that in 2011, minimum investment was 600 million rupiah in Ponorogo Regency, and the maximum value was $230.446,84$ million rupiah in Jember regency, and the average investment value of Regency / cities amounted to 34.645.88 million rupiah. In 2012 the minimum investment value of 217.67 million rupiah in Blitar Regency, and the maximum value of 100.207 million rupiah in Sampang Regency. In 2013 a minimum investment value of 200 million rupiahs in Probolinggo Regency, and a maximum value of 305.568 million rupiah in Jember Regency, and an average investment value of Regency / cities of 52.893 million rupiah. In 2014 a minimum investment value of 200 million rupiahs in Probolinggo Regency, and a maximum value of 85,000 million rupiah in Bojonegoro Regency, and an average investment value of Regency / cities of 13.404 million rupiah. And in 2015 the minimum value of 250 million rupiah in Magetan regency, and the maximum value of 183.451.56 million rupiah in Pacitan regency, and the average investment value of Regency / cities amounted to 14.452 million rupiah.

Capital Expenditure, in 2011 the minimum value of 50.302 million rupiah in Mojokerto Regency, and maximum value of 543.112 million rupiah in Surabaya City, and the average value of capital expenditure of regencies / cities amounted to 164.375 million rupiah. In 2012 the minimum value of 65,462 million rupiahs in Batu City, and the maximum value of 912.716 million rupiah in Surabaya City, and the average value of capital expenditure of regencies / cities amounted to 227.062 million rupiah. In 2013 the minimum value of 67.646 million rupiahs in Mojokerto Regency, and the maximum value of 1,281,395 million rupiahs in Surabaya City, and the average value of capital expenditures Regency / cities amounted to 262,383 million rupiah. In 2014 a minimum value of 106,923 million rupiahs in Probolinggo City, and a maximum value of 1,404,366 rupiahs in Surabaya, and an average value of Regency capital expenditure of 335,392 million rupiah. In 2015 the minimum value of 97.189 million rupiahs in Surabaya City, and the maximum value of 464.305 million rupiah in Pasuruan, and the average value of capital expenditure Regency / city of 181.053 million rupiah.

The independence of Regional Finance, demonstrates the ability of local governments to finance government activities, development and services to communities that have paid taxes and levies as a necessary source of income (Halim, 2002: 128). Criteria of financial ability, independence ratio and Pattern of Relationship can be explained (Dwirandra, 2007: 7) as follows:

1) Very low financial ability Once, if the ratio of $0-25 \%$, and called the pattern of instructive relationship.

2) Low financial ability, if the ratio of $>25-50 \%$, and called the pattern of consultative relationships.

3) Medium financial ability, if the ratio of $>50-75 \%$, and called the pattern of participatory relationships.

4) High financial ability, if the ratio of $>75-100 \%$, and called the pattern of delegative relationships. 
Aspects of Regional Financial Independence Ratio in 2011 minimum value of 6.04\% in Sampang Regency, and the maximum value of $47.36 \%$ in Surabaya City, and the average value of Regency / city self-reliance ratio of $12.46 \%$. In 2012 the minimum value of $6.53 \%$ in Pacitan Regency, and the maximum value of $96.81 \%$ in the city of Surabaya, and the average value of the ratio of Regency / city financial independence of $14.77 \%$. In 2013 the minimum value of $6.61 \%$ in Sampang Regency, and the maximum value of $114.24 \%$ in the city of Surabaya, and the average value of the ratio of regency/city financial independence of $16.93 \%$. In 2014 the minimum value was $1.71 \%$ in Blitar Regency, and the maximum value of $121.53 \%$ in Surabaya City, and the average value of the ratio of Regency / city financial independence of $20.18 \%$. In 2015 the minimum value of $9.45 \%$ in Pamekasan Regency, and the maximum value of $115.84 \%$ in the city of Surabaya, and the average value of the Regency's financial independence ratio of $20.72 \%$.

Economic growth in 2011, a minimum value of 2.50\% in Sampang Regency, and a maximum value of $10.39 \%$ in Bojonegoro Regency, and the average rate of economic growth of the regencies / municipalities was $6.13 \%$. In 2012 the minimum value of $-1.42 \%$ in Bangkalan regency, and the maximum value of $9.96 \%$ in Sumenep regency, and the average rate of economic growth of the Regency / city by $6.22 \%$. In 2013 the minimum value of $0.19 \%$ in Bangkalan regency, and the maximum value of $14.14 \%$ in Sumenep regency, and the average rate of economic growth of the Regency / city by $6.05 \%$. In the year 2014 the minimum value of $0.07 \%$ in Sampang Regency, and the maximum value of $7.19 \%$ in Bangkalan regency, and the average rate of economic growth of the Regency / city by 5.57\%. In 2015 the minimum value of 5.26\% in Batu City, and the maximum value of $7.24 \%$ in Madiun Regency and the average rate of economic growth of the Regency / city was $6.10 \%$.

The absorption of manpower, in 2011, the minimum value of 57.101 people in Mojokerto City, and the maximum value of 1,230,165 people in Surabaya, and the average labor absorption rate in regency / municipality was 489,602 people. In 2012 the minimum value of 61,407 people in Mojokerto City, and the maximum value of 1.361 .648 people in the city of Surabaya, and the average rate of employment absorption in the Regency / city of 510,823 people. In 2013 the minimum value of 62,123 people in Mojokerto City, and the maximum value of 1,404,445 people in the city of Surabaya, and the average value of labor absorption in the Regency / city of 514,577 people.

In 2014 the minimum value of 61,771 people in Mojokerto City, and the maximum value of 1,380,157 people in Surabaya, and the average rate of employment absorption in the Regency / city was 508,066 people. In 2015 a minimum value of 63,806 people in Mojokerto City, and a maximum value of 1,365,180 people in Surabaya, and an average labor absorption rate in Regency / cities of 509,678 people. People's Welfare / Human Development Index that can show human progress based on factors, such as average life expectancy, average school length, literacy rate, and overall prosperity.

According to BPS there are four categories of HDI figures, namely:

Low HDI $<50$

Medium - Below $50<$ IPM $<66$

Intermediate $66<$ IPM $<80$

High $\mathrm{HDI} \geq 80$ 
Community Prosperity/ Human Development Index, in 2011 minimum IPM of 60.78 in Sampang Regency, and a maximum HDI of 77.89 in Blitar City, and the average value of Regency / city IPM of 71.29. In 2012 the minimum IPM of 61.67 in Sampang Regency, and the maximum IPM of 78.43 in Malang, and the average value of Regency / city IPM of 71.87. In 2013 minimum IPM of 62.39 in Sampang Regency, and a maximum HDI of 78.97 in Surabaya, and the average value of Regency / city IPM of 72.44. In 2014 the minimum IPM of 56.98 in Sampang Regency, and the maximum HDI of 78.96 in Malang, and the average value of Regency / city IPM of 68.37. In 2015 the minimum IPM of 58.18 in Sampang Regency, and the maximum HDI of 80.05 in Malang, and the average value of Regency / city IPM of 69.11.

Inter-regional disparity, or inequality between regions calculated by Williamson's Index. Williamson's index criterion is: The numbers of 0.0 to 0.2 are low inequality; the numbers 0.21 to 0.35 are medium; number $>0.35$ high. Factors of Inter-Regional Disparity / Williamsons Index in 2011, minimum index of 0.0037 in Mojokerto Regency, and maximum index of 0,5932 in Surabaya City, and the mean value of Regency / Municipal Williamson Index of 0.0955. In 2012 the minimum index was 0,0041 in Mojokerto Regency, and the maximum index was 0,6001 in Surabaya, and the mean value of Regency / Municipal Williamson Index was 0,0956. In 2013 the minimum index was 0.0038 in Mojokerto regency, and the maximum index was 0.6130 in Surabaya, and the average value of the Regency / city Williamson Index was 0.0953. In 2014 the minimum index was 0.0017 in Bojonegoro Regency, and the maximum index was 0.6216 in Surabaya City, and the average value of the Regency of Williamson Index was 0.0957. By 2015 the minimum index was 0.0015 in Bojonegoro, and the maximum index was 0.5875 in Surabaya, and the mean value of the Regency / city Williamson Index was 0.0934.

Gini Ratio, Gini coefficient was a measure of aggregate inequality and the value lies between 0 (perfect equity) to 1 (perfect impermanence). Countries experiencing high inequality, Gini coefficient values ranging from 0.50 - 0.70 ; moderate inequality ranges from 0.36 to 0.49 ; and those with low inequality ranged from 0.20 to 0.35 (Arsyad, 2010: 291). Inter-Regional Income Disparities / Gini Ratio in 2011 minimum index of 0.26 in Situbondo and Sampang Regency, and Gini Ratio maximum of 0.39 in Kediri City, and average Gini Ratio of Regency / city ratio of 0.31.

In 2012 the minimum index was 0.24 in Pamekasan Regency, and Gini Ratio was maximum of 0.48 in Malang City, and the average value of Gini Ratio of regencies / cities was 0.32. In 2013 the minimum index was 0.23 in Lumajang Regency, and the Gini Ratio was 0.43 in Madiun City, and the Gini Ratio of Regency / city was 0.32. In 2014 the minimum index was 0.23 in Lumajang and Sampang Regency, and the Gini Ratio was 0.39 in Surabaya, and the Gini Ratio of Regency / city was 0.30 . In 2015 the minimum index was 0.26 in Sumenep Regency, and the Gini Ratio was 0.42 in Surabaya, and the Gini Ratio of Regency/city was 0.34 .

\subsection{Path Analysis}

Path analysis of each exogenous variable to indogenous variable consisting of several variables, namely: Ratio of Regional Financial Independence (X1), Local Government Capital Expenditure (X2), Government Investment (X3), Economic Growth (Y1), Employment Absorption (Y2), Public Welfare (Y3), and variable of Inter-Region Disparity (Z1) and Income Disparity (Z2) as complete moderating variable can be seen in Figure 2 below: 


\section{Path Analysis}

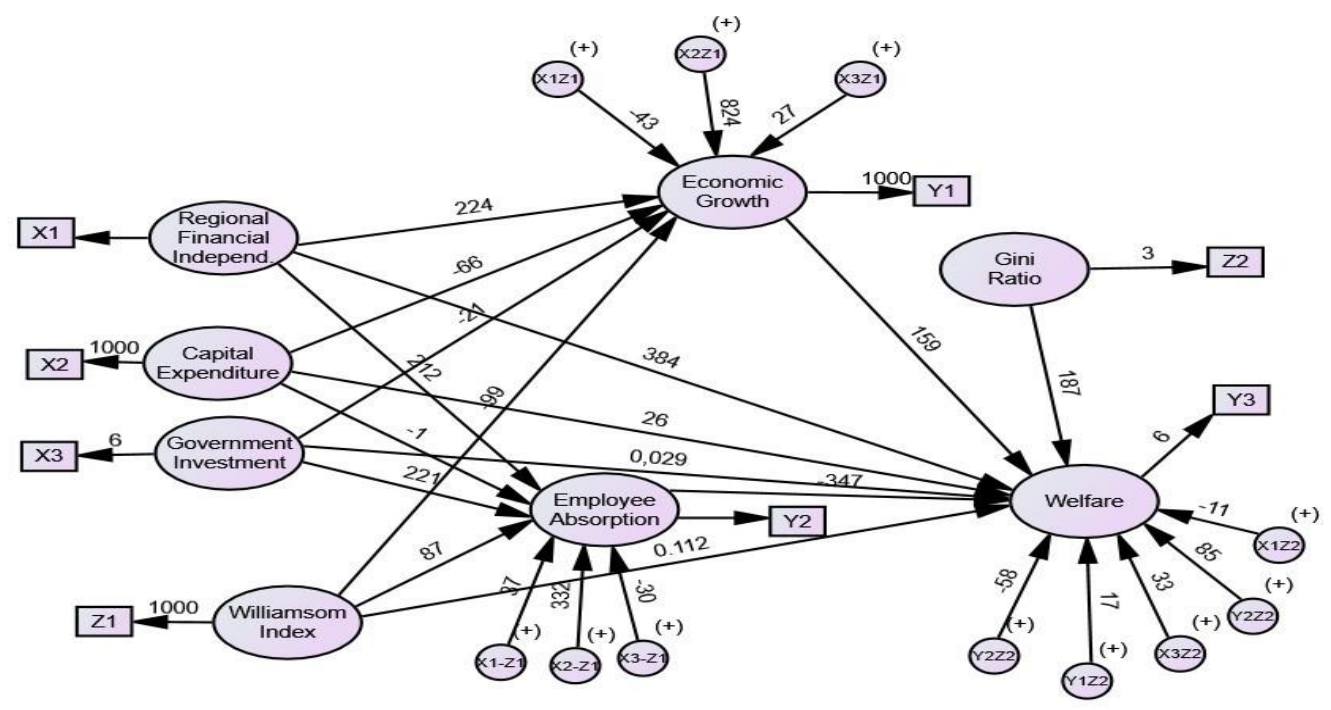

Figure 2: Test Hypotheses

From figure 2 in accordance with the proposed hypothesis obtained some path equations as follows:

$$
\text { 1) } \begin{aligned}
& Y_{1}=b_{1} X_{1}+b_{2} Z_{1}+b_{3} X_{1} * Z_{1} \\
& \mathrm{Y}_{1}=0,224 \mathrm{X}_{1}-0,099 \mathrm{Z}_{1}-0,043 \mathrm{X}_{1} * \mathrm{Z}_{1} \\
& \text { 2) } Y_{2}=b_{1} X_{1}+b_{2} Z_{1}+b_{3} X_{1} * Z_{1} \\
& \mathrm{Y}_{2}=0,212 \mathrm{X}_{1}+0,087 \mathrm{Z}_{1}+0,037 \mathrm{X}_{1} * \mathrm{Z}_{1} \\
& \text { 3) } Y_{3}=b_{1} X_{1} \\
& \mathrm{Y}_{3}=0,384 \mathrm{X}_{1} \\
& \text { 4) } Y_{1}=b_{1} X_{2}+b_{2} Z_{1}+b_{3} X_{2} * Z_{1} \\
& \mathrm{Y}_{1}=-0,066 \mathrm{X}_{2}-0,099 \mathrm{Z}_{1}+, 824 \mathrm{X}_{2} * \mathrm{Z}_{1} \\
& \text { 5) } Y_{2}=b_{1} X_{2}+b_{2} \mathrm{Z}_{1}+b_{3} X_{2} * Z_{1} \\
& \mathrm{Y}_{2}=-0,001 \mathrm{X}_{2}+0,087 \mathrm{Z}_{1}+0,332 \mathrm{X}_{2} * \mathrm{Z}_{1} \\
& \text { 6) } Y_{1}=b_{1} X_{3}+b_{2} \mathrm{Z}_{1}+b_{3} X_{3} * Z_{1} \\
& \mathrm{Y}_{1}=-0,021 \mathrm{X}_{3}-0,099 \mathrm{Z}_{1}+0,027 \mathrm{X}_{3} * \mathrm{Z}_{1} \\
& \text { 7) } Y_{2}=b_{1} X_{3}+b_{2} Z_{1}+b_{3} X_{3} * Z_{1} \\
& \mathrm{Y}_{2}=0,221 \mathrm{X}_{3}+0,087 \mathrm{Z}_{1}-0,030 \mathrm{X}_{3} * \mathrm{Z}_{1} \\
& \text { 8) } Y_{3}=b_{1} Y_{1}+b_{2} Z_{2}+b_{3} Y_{1} * Z_{2} \\
& \mathrm{Y}_{3}=0,159 \mathrm{Y}_{1}+0,187 \mathrm{Z}_{2}+0,017 \mathrm{Y}_{1} * \mathrm{Z}_{2} \\
& \text { 9) } Y_{3}=b_{1} Y_{2}+b_{2} Z_{2}+b_{3} Y_{2} * Z_{2} \\
& \mathrm{Y}_{3}=-0,347 \mathrm{Y}_{2}+0,187 \mathrm{Z}_{2}-0,058 \mathrm{Y}_{2} * \mathrm{Z}_{2} \\
& \text { 10) } Y_{3}=b_{1} X_{3} \\
& \mathrm{Y}_{3}=0,029 \mathrm{X}_{3}
\end{aligned}
$$

\subsection{Results of Hypothesis Testing}

The result of hypothesis testing 1, direct influence of regional financial independence variable to economic growth shows that path coefficient value equal to 0,224 with probability error equal to 
0,013 smaller than level of significance $(\alpha) 0,05$, this indicates that local financial independence have positive and significant influence to economic growth. The indirect influence of variable of regional financial independence with moderate effect of disparity between regions on economic growth shows the coefficient value of -0.043 with a probability error value of 0.325 greater than the significance level $(\alpha) 0.05$. This means that regional financial independence with moderate effects of disparity between regions has a negative but insignificant effect on economic growth.

The result of hypothesis testing 2, direct influence of variable of regional financial independence to the absorption of labor shows that path coefficient value of 0.212 with probability error of 0.154 greater than the level of significance $(\alpha) 0.05$, this means that the regional financial independence has a positive but not significant effect on absorption labor. The indirect influence of variable of regional financial independence with moderate effect of disparity between regions on labor absorption showed the value of path coefficient of 0.037 with error probability value of 0.608 greater than the significance level $(\alpha) 0.05$. This means that regional financial independence with moderate effects of disparity between regions has a positive but not significant effect on employment. Result of hypothesis testing 3, direct influence of variable of regional financial independence to public welfare show path coefficient value equal to 0,384 with probability. Result of hypothesis testing 4, direct influence of variable of local government capital expenditure to economic growth show path coefficient value equal to $-0,066$ with error probability equal to 0,687 bigger than level of significance $(\alpha) 0.05$, this means that local government capital expenditure has negative and insignificant effect on economic growth. The indirect effect of variable of local government capital expenditures with moderate effects of disparity between regions on economic growth shows that path coefficient value of 0.824 with an error probability value of 0.569 greater than the significance level $(\alpha)$ 0.05. This shows that local government capital expenditure with moderate effect of disparity between regions has positive but not significant effect on economic growth. Result of hypothesis testing 5, direct influence of variable of local government capital expenditure to the absorption of labor show path coefficient value equal to $-0,001$ with probability error 0,998 bigger than level of significance $(\alpha) 0,05$, this means that local government capital expenditure has negative and not significant on the absorption of manpower. Indirect effect of variable of local government capital expenditures with moderate effects of inter-regional disparity on labor absorption showed path coefficient value of 0.332 with error probability value of 0.854 greater than the significance level $(\alpha) 0.05$. This means that local government capital expenditures with moderate effects of disparity between regions have a positive but not significant effect on labor absorption.

Result of hypothesis testing 6, direct influence of variable of local government investment toward economic growth show path coefficient value equal to $-0,021$ with error probability equal to 0,678 bigger than level of significance $(\alpha) 0,05$, it means that local government investment have negative and insignificant effect to economic growth. The indirect effect of local government investment variables with the effect of moderate disparity between regions on economic growth shows the value of path coefficient of 0.027 with a probability error value of 0.637 greater than the significance level $(\alpha) 0.05$. This means that local government investment with moderate effects of disparity between regions has a positive but insignificant effect on economic growth.

The results of hypothesis testing analysis 7, direct influence of local government investment variable on employment absorption showed path coefficient value of 0.221 with a probability error 
of 0.033 smaller than the significance level $(\alpha)$ 0.05, this indicates that local government investment has a positive and significant impact on employment.

The indirect effect of local government investment variables with the effect of moderate disparity between regions on labor absorption shows the coefficient value of the path of -0.030 with a probability error value of 0.912 greater than the significance level $(\alpha) 0.05$. This means that local government investment with moderate effects of disparity between regions has a negative but not significant effect on labor absorption.

Result of hypothesis testing 8, direct influence of economic growth variable to society welfare shows path coefficient value equal to 0,159 with error probability 0,005 smaller than level of significance $(\alpha) 0,05$, it means that economic growth have positive and significant effect to society prosperity.

The indirect effect of economic growth variable with the moderation effect of income disparity on public welfare shows the value of path coefficient of 0,017 with error probability value equal to 0,826 bigger than level of significance $(\alpha) 0,05$. This means that economic growth with moderate effects of income disparity has a positive but insignificant effect on people's welfare.

The result of hypothesis testing 9, direct influence of variable of labor absorption toward social welfare shows path coefficient value equal to $-0,347$ with error probability equal to 0.000 less than level of significance $(\alpha) 0,05$, this means that labor absorption have negative and significant effect to welfare community.

The indirect effect of labor absorption variable with the moderate effect of income disparity on the welfare of the community shows the coefficient value of -0.058 with the error probability value of 0.274 greater than the significance level $(\alpha) 0.05$. This means that employment absorption with moderate effects of income disparity has a negative but insignificant effect on people's welfare.

Result of hypothesis testing 10, direct influence of variable of local government investment to public welfare show value of coefficient of path equal to 0,029 with probability error equal to 0,568 bigger from level of significance $(\alpha) 0,05$, this means that local government investment have positive but not significant to welfare community.

\subsection{General Discussion}

Direct influence, local financial independence has a positive and significant impact on economic growth. That is, the greater the portion of Regional Real Revenue (PAD) to total regional revenue will encourage economic growth. These findings support the research of Ni Luh Nana Putri Ani and A.A.N.B. Dwirandra (2014) and Mursinto (2004). But the indirect influence of local financial independence with moderating effects has a negative but insignificant effect on economic growth. Thus the disparity between regions has the effect of weakening the influence of regional financial independence on economic growth or can be called as constraints / diseases of economic growth. This was a new finding as well as a novelty of the results of this study, that the disparity between regions that have a debilitating effect can be regarded as a constraint or disease for economic growth. Thus it can be concluded that the variable disparity between regions was acted as a 
moderation variable on the influence of independence regional finance to economic growth, although not significant.

Mursinto research (2014) concludes that, from the aspect of regional revenue and expenditure, none of the Regency and cities in East Java Province have been able to independently implement regional autonomy due to the low Regional Real Revenues (PAD) although it has been added with Taxes Result and Non-Tax (BHPBP) of regencies and cities in East Java Province.

The direct influence of regional financial independence ratio on the absorption of the manpower shows a positive but not significant effect on the absorption of labor. While the indirect effect indicates a positive but not significant effect. The results of the research support previous research conducted by Ni Luh Nana Putri Ani and A.A.N.B. Dwirandra (2014) and Djoko Mursinto (2004). The bigger portion of Regional Real Revenue (PAD) to total regional revenue did not encourage the absorption of labor. Disparity between regions also has the effect of weakening the absorption of labor. In general, it was illustrated that the last five years there was a high gap from the aspect of the ratio of regional financial independence among Regency / cities in East Java, and the city of Surabaya was the city with the highest Regional Financial Independence Ratio that becomes the target of urban workers from other regions.

The direct influence of local financial independence on community welfare has a positive and significant effect. This means that the greater the portion of Regional Real Revenue to total regional revenue will further encourage the increase in the welfare of the community. Surabaya city that was able to have a pattern of delegative relationship shows able to finance its own government activities with PAD gained and acts as the economic center of East Indonesia region. Increased Regional Real Income (PAD) was considered as an accumulated capital that will generate positive externalities and will accelerate economic growth (Amin Pujiati, 2008: 10), which in turn will improve the welfare of the community.

Direct Influence of Local Governments Capital Expenditures on economic growth are negatively insignificant. The greater spending of local government capital will further decline economic growth. This research supports the research results of Agung Priambodo (2014), indirect influence of local government capital expenditure with moderate effect of disparity between regions on economic growth based on the analysis result has positive but insignificant impact on economic growth. This was a new finding as well as a novelty of the results of this study, because so far researchers have not found any other researchers who place disparity between regions as a moderator variable in his research. The influence of capital expenditure on economic growth initially negatively affected, with the effect of moderate disparity between regions, the effect changed to positive (in accordance with Harrod-Domar's theory). The results of this study also do not support research conducted by Hendarmin (2012); Santi Nurmainah (2012); Eunike Elisabeth Bawuno (2015); Basri Bado (2015), whose research concludes that capital spending has a positive effect on economic growth.

This situation shows that the disparity between regions has the effect of strengthening the influence of regional government capital expenditure on economic growth. Thus it can be concluded that the variable disparity between regions was acted as a moderation variable on the influence of local government capital expenditure on economic growth, although not significant. 
The direct influence of local government capital spending on the absorption of manpower was negative and insignificant. The greater the share of local government expenditure (capital expenditure) will reduce the rate of employment. During the period of 2006-2015 capital expenditures implemented by Regency / municipality governments in East Java such as infrastructure / public facilities and services have no effect on the increment of employment. It can be assumed that the economic growth has not been able to create / expand new jobs. This suggests that the approach used for economic growth was not a labor intensive but capital intensive approach, that is, the approach of economic growth that uses more capital than labor, so that income was only enjoyed by a few people. This finding does not support the research of Lailan Safina and Sri Endang Rahayu (2011) which concluded that the investment projected as government capital expenditure has a positive and significant effect on job creation. The indirect effect of government capital expenditures with moderate effect of disparity between regions on the absorption of manpower is positive but insignificant. This situation shows that the disparity between regions has the effect of strengthening the influence of local government capital expenditure on employment.

This was a new finding as well as a novelty of the results of this study, that the disparity between regions have the effect of strengthening the influence of capital expenditure on employment although not significant. It is a novelty of this research because so far researchers have not found any other researchers who put disparity between regions as a moderator variable in his research. Thus it can be concluded that the variables of disparity between regions was acted as a moderator variable on the influence of local government capital expenditure on employment, although not significant.

The direct influence of local government investment on economic growth is negative and insignificant. The larger local government investment will reduce economic growth. This study supports the research of Baffes and Anwar (1998); Sala-I-Martin (1997); which concluded that government investment had a negative but insignificant effect. On the other hand, this study does not support the research of Dessus and Remy (2000); Barro (1991); Kim (1997); Samuel Korua, Rumate and Hanly (2016); Safina and Rahayu (2011); Maharani and Sri Isnowati (2014); Danawati, Bendesa and Sanyana Utama (2016), which concluded that local government investment has a positive effect on economic growth. The indirect effect of local government investment with the effect of moderate of disparity between regions on economic growth was positive but not significant. This situation shows that the disparity between regions has the effect of strengthening the influence of local government investment on economic growth. This was a new finding as well as a novelty of the results of this study, that the disparity between regions that have the effect of strengthening the influence of local government investment on economic growth. It is acted as a novelty of this research because so far researchers have not found any other researchers who put disparity between regions as a moderator variable in his research. Thus it can be concluded that the variable of disparity between regions was acted as a moderation variable on the influence of local financial independence on economic growth, although not significant.

The direct influence of local government investment on employment was positive and significant. Higher local government investment increases employment. This study supports the results of previous research by Esterly and Levine (2002); Safina and Rahayu (2011), which concluded that local government investment has a positive effect on the absorption of manpower. The indirect 
effect of local government investment with moderation effect of disparity between regions on the absorption of labor has a negative and insignificant effect on labor absorption.

This situation shows that the disparity between regions has the effect of weakening the influence of local government investment on employment. This was a new finding as well as a novelty of the results of this study, that the disparity between regions has a debilitating effect that can be regarded as a constraint or disease for the absorption of labor. Called as a novelty of this research because so far researchers have not found any other researchers who put disparity between regions as a moderator variable in his research. Thus it can be concluded that the variable disparity between regions was as a moderator variable on the influence of local government investment on employment absorption.

The direct influence of economic growth on the well-being of the people was positive and significant. This research supports the results of previous research by Yasa and Arka (2015); Mirza (2012) which concludes that economic growth has a positive and significant impact on people's welfare. This study also supports the theory of the optimum pareto developed by Wilfredo Pareto which states that economic growth can be used to improve the collective welfare of the community composed of individuals in society. The indirect effect of economic growth with the moderate effects of income disparity on the welfare of society was positive but not significant. This situation shows that income disparity has the effect of weakening the influence of economic growth on the welfare of society. The effect of moderation (the debilitating effect) of the income disparity on the effect of economic growth on the welfare of society was shown by the existence of a direct positive and significant effect that becomes insignificant on its indirect effect.

This was a new finding as well as a novelty of the results of this study, that the disparity of income that has the effect of weakening can be regarded as a constraint or disease for improving the welfare of the community. Called as a novelty of this research because so far researchers have not found any other researchers who put income disparity as a moderator variable in his research. Thus it can be concluded that income disparity variable was as a moderator variable on the influence of economic growth on the welfare of the community, although not significant.

The direct influence of labor absorption on public welfare was negative and significant. With the higher level of employment will further lower the level of community welfare. This finding does not support Kim's (1997) research results; Baffes (1998) and Dessus (2000) and Sulistiawati (2012) concluded that employment absorption has a positive but insignificant effect on welfare. The absorption of workers which have not been able to improve the welfare of the community shows that the determination of wages not only based on the level of education and skills but also set a different Regional Minimum Wage (UMR) between urban Regency in East Java province. Hasna (2013: 13) in the results of his research concluded that the level of UMR in East Java has a positive effect on the distribution of income.

The indirect effect of labor absorption with the moderating effects of income disparity on prosperity was negative and insignificant. It means that income disparity does not have the effect of either weakening or strengthening the influence of labor absorption on people's welfare. Thus it can be concluded that income disparity variable was not acted as a moderation variable on the influence of the absorption of manpower to economic growth. 
The direct influence of local government investment on public welfare was positive but insignificant. Increase in local government investment that was not able to improve the welfare of the community in a better direction was caused by the allocation of funds for uneven investment between Regency / cities in East Java Province. This situation was not balanced with the average development of stable Human Development Index (HDI), but even very volatile. This disproportionate change causes an increase in local government investment has not been able to improve the welfare of the community towards a better, so that the influence of local government investment on the welfare of society has a positive but not significant effect.

\section{Conclusion}

Based on the results of data analysis and discussion that have been described previously, then some conclusions are presented:

1) Regional financial independence has a positive and significant impact on economic growth, while regional financial independence with moderate effects of disparity between regions has a negative but not significant effect on economic growth. Inter-regional disparity has the effect of weakening the influence of regional financial independence on economic growth, so the disparity between regions serves as a moderator variable on the influence of local financial independence on economic growth, although not significant.

2) Regional financial independence has a positive and insignificant effect on labor absorption, while regional financial independence with moderate effects of disparity between regions has a positive and insignificant effect. So the disparity between regions was not as a moderator variable on the influence of local financial independence on employment.

3) Regional financial independence has a positive and significant impact on the welfare of the community. With the increasing independence of regional government in financing its development, the level of welfare of the community was increasing.

4) Regional government capital expenditure has negative and insignificant effect on economic growth, while regional government capital expenditure with moderate effect of disparity between regions has positive and insignificant effect on economic growth. Inter-regional disparity has the effect of strengthening the influence of local government capital expenditure on economic growth, so the disparity between regions serves as a moderator variable on the influence of local government capital expenditure on economic growth, although not significant.

5) Local government capital expenditure has negative and insignificant effect on labor absorption, while regional government capital expenditure with moderate effect of disparity between regions has positive and insignificant effect on labor absorption. Interregional disparity has the effect of strengthening the influence of regional government capital expenditure on employment absorption, so that the disparity between regions was as a moderator variable on the influence of local government capital expenditure on employment although not significant.

6) Local government investment has negative and insignificant effect on economic growth, while local government investment with moderate effect of inter-regional disparity has a positive effect on insignificant to economic growth. Disparity between regions has the effect of strengthening the influence of local government investment on economic growth, so that the disparity between regions was as a moderator variable on the influence of local government investment on economic growth, although not significant. 
7) Local government investment has a positive and significant impact on labor absorption, while local government investment with moderate effects of disparity between regions has a negative and insignificant effect on labor absorption. Inter-regional disparity has the effect of weakening the influence of local government investment on labor absorption, so the disparity between regions was as a moderator variable on the influence of local government investment on employment although not significant.

8) Economic growth has a positive and significant impact on the welfare of the community, while the economic growth with the effect of moderation income disparity has a positive but insignificant effect on the welfare of society. Income disparity has the effect of weakening the influence of economic growth on the welfare of society, so that income disparity was as a moderator variable on the influence of economic growth on the welfare of the community although not significant.

9) Absorption of labor has a negative and significant effect on the welfare of the community, while the absorption of labor with the effect of moderation of income disparity has a negative and insignificant effect on the welfare of the community. Income disparity has the effect of weakening the influence of labor absorption on the welfare of the community, so the income disparity was as a moderator variable on the effect of employment on the welfare of the community, although not significant.

10) Local government investment has a positive and insignificant effect on people's welfare. Increased local government investment spending does not provide much improvement in the welfare of the people.

\subsection{Recommendations}

Policies to improve local financial independence are always tailored to the characteristics and potentials of each Regency / city. Local governments should be able to increase local revenues and can make efficiency in regional expenditures. Strategies to increase region income, local governments can intensify local taxes by utilizing existing resources by providing socialization and extension to taxpayers, thereby fostering public awareness to pay local taxes and levies. Besides, it can also be done extensification local taxes, that is looking for sources of taxes and other levies or expand the scope of taxes and other charges that are really specific and potential in the region.

In order to reduce income inequality, development planning should be prioritized for relatively lagging areas. For equal distribution of allocation of funds, adjustment of the highest Special Allocation Fund and General Allocation Fund was granted to the Regency / cities with the lowest $\mathrm{DBH}$, and vice versa.

Regency / city governments and local governments of East Java Province have time to seek to improve Human Development Index (HDI) primarily indicator level of education and health.

The government will immediately realize the development of infrastructure that provides widespread benefits to the community; such as roads, bridges, air and sea ports, electricity and water supply, telecommunication networks, irrigation canals and dams. In addition to reducing unemployment and poverty, the availability of infrastructure can be an attractive investment and 
at the same time can increase the capacity and efficiency of businesses in the productive economy sector.

\section{References}

[1] Amin, Pujiati, (2008). Analisis Pertumbuhan Ekonomi di Karesidenan Semarang Era Desentralisasi Fiskal. Jurnal Ekonomi Pembangunan Kajian Ekonomi Negara Berkembang hal. 61-70.

[2] Ani, Ni Luh Nana Putri dan Dwirandra. (2014). Pengaruh Kinerja Keuangan Daerah Pada Pertumbuhan Ekonomi. Pengangguran dan Kemiskinan Kabupaten dan Kota. Jurnal Akuntansi. Vol.6 No.3

[3] Arsyad, Lincolin. (2004). Ekonomi Pembangunan. Edisi Keempat. Yogyakarta: STIE YKPN.

[4] Arsyad, Lincolin. (2010). Ekonomi Pembangunan Edisi Kelima, UPP STIM YKPN.

[5] Boex Jamie (2011). Exploring the Measurement and Effectiveness of the Local Public Sector: Toward a classification of local public sector finances and a comparison of devolved and deconcentrated finances. IDG Working Paper No. 2011-05.

[6] Badan Pusat Statistik. (2009). Statistik Indonesia 2009, Nomor Katalog : 1101001, Nomor Publikasi : 07330.0913, ISSN / ISBN : 0126-2912.

[7] Badan Pusat Statistik. (2011). Indikator Makro Ekonomi Provinsi Jawa Timur, BPS.

[8] Badan Pusat Statistik (2012). Jawa Timur Dalam Angka. 2011. Surabaya: Badan Pusat Statistik Jawa Timur.

[9] Baffes, John and Anwar Shah, (1998). Productivity of Public Spending, Sectoral Allocation Choice, and Economic Growth, Economic Development and Culture Change, Vol. 46, No. 2: 291-303.

[10] Barro, R.J. (1991). Economic Growth in a Cross Section of Countries. Quarterly Journal of Economics, 106, 407-444.

[11] Basri Bado, (2015). Analisis Belanja Modal , Investasi dan Tenaga Kerja terhadap Pertumbuhan Ekonomi Sulawesi Selatan, Journal EkonoSain, Volume XIII, Nomor 2.

[12] Danawati, (2016). Pengaruh Pengeluaran Pemerintah dan Investasi Terhadap Kesempatan Kerja, Pertumbuhan Ekonomi Serta Ketimpangan Pendapatan Kabupaten/ Kota di Provinsi Bali. E-Jurnal Ekonomi dan Bisnis Universitas Udayana. Volume 5. Nomor 7. ISSN: 2337-3067.

[13] Denni Sulistio Mirza (2012). Pengaruh Kemiskinan, Pertumbuhan Ekonomi, Dan Belnja Modal Terhadap Indeks Pembangunan Manusia Di Jawa Tengah Tahun 2006-2009, Economics Development Analysis Journal, 1 (1) ISSN 2252-6560, Universitas Negeri Semarang

[14] Dessus, Sebastian and Remy Herrera, (2000). Public Capital and Growth Revisied: A Panel Data Assesment, Economic Development and Culture Change, Vol.102: pp.407 - 419.

[15] Dwirandra, A.A.N.B. (2007). "Efektivitas dan Kemandirian Keuangan Daerah Otonom Kabupaten/kota di Propinsi Bali tahun 2002 - 2006”, Jurusan Akuntansi Fakultas Ekonomi, Universitas Udayana

[16] Easterly, W., \& Roos Levina. (2002). Tropics, Germs and Crops : How Endowments Influence Economics Development National Bureau of Economic Research Working Paper 9106 Augustus 2002

[17] Eunike Elisabeth Bawuno, (2015). Pengaruh Investasi Pemerintah dan Tenaga Kerja terhadap PertumbuhanEkonomi di Kota Manado (Studi Pada Kota Manado Tahun 2003-2012), Jurnal Berkala Ilmiah Efisiensi, Volume 15 No. 04 Tahun 2015

[18] Fernando Samuel Korua, (2016). Pngaruh Investasi Pemerintah terhadap Pertumbuhann Ekonomi melalui Tenaga Kerja sebagai Intervening Variabel di Propinsi Sulawesi Utara Tahun 2003 -2013, Jurnal Berkala Ilmiah Efisiensi Vol. 16 No. 01.

[19] Halim, Abdul (2001). Manajemen keuangan daerah: bunga rampai, Penerbit : UPP AMP YKPN, ISBN 20019798170725, 9789798170720

[20] Halim, Abdul. (2002). Seri Bunga Rampai: Akuntansi dan Pengendalian Keuangan Daerah. Yogyakarta: UPP AMP YKPN 
[21] Hasna, Shofwatun. (2013). Analisis Spasial Pengaruh Dana Perimbangan Terhadap Ketimpangan Pendapatan di Provinsi Jawa Timur Tahun 2008- 2011. Jurnal BPPK. Vol. 6 No. 2

[22] Hendarmin, (2012). Pengaruh Belanja Modal Pemerintah Daerah dan Investasi Swasta terhadap Pertumbuhan Ekonomi, Kesempatan Kerja dan Kesejahteraan Masyarakat di Kabupaten/Kota Provinsi Kalimantan Barat", Jurnal Eksos, Vol.8, No. 3, Hal.144-155.

[23] Ikatan Akuntan Indonesia, (2009). Pernyataan Standar Akuntansi Keuangan PSAK No. 2: Laporan Arus Kas, Akuntansi Standar 657.0218, http://lib.ibs.ac.id:80/index.php?p=show_detail\&id=1115

[24] Kim, Sung Tai, (1997). The Role of Local Publik Sector in Regional Economic Growth in Korea. Asian Economic Journal, Vol. 11, No. 21 : pp. 155-168.

[25] Kuncoro, Mudrajad. (2003). Metode Riset untuk Bisnis \& Ekonomi. Jakarta: Erlangga.

[26] Maharani, Kurnia dan Isnowati, Sri. (2014). Kajian Investasi, Pengeluaran Pemerintah, Tenaga Kerja dan Keterbukaan Ekonomi Terhadap Pertumbuhan Ekonomi di Provinsi Jawa Tengah. Jurnal Bisnis dan Ekonomi. Hal. 62-72. Vol 21, No 1.

[27] Mahmudi, (2010). Analisis Laporan Keuangan Pemerintah Daerah, Panduan Bagi Eksekutif, DPRD dan Masyarakat Dalam Pengambilan Keputusan Ekonomi, Sosial dan Politik, Edisi kedua, UPP STIM YKPN, Yogyakarta.

[28] Mirza Denni Sulistio, (2012). "Pengaruh Kemiskinan, Pertumbuhan Ekonomi, dan Belanja Modal Terhadap Indeks Pembangunan Manusia di Jawa Tengah Tahun 2006-2009",Jurnal Ekonomi Pembangunan, Universitas Negeri Semarang, ISSN 2252-6560, Hal. 1-15.

[29] Mursinto, Djoko, (2004). (Influence of Fiscal Decentralization Degree and Financial Independence Leveland also Elasticity of Regional Original Revenue to the Category of Regency/City Government Administration at the Initial Stage of Regional Autonomy in East Java Province). Dissertation. Surabaya: Post Graduate Program or Airlangga University.

[30] Mursinto, Djoko, (2014). Influence of Government Investmen and Private Investmen to Economic Growth, Manpower Absorption and Amount of Poor Population in Regencies/Cities in South Kalimantan Province in 2002-2012, Journal of Economics and Development (Paper) ISSN 22222855 (Online) Vol 5 No 26, 2014 Journal of Economics and Development http://www.iiste.org/journals/ ISSN 2222-1700

[31] Nurmainah,Santi, (2012). Analisis Pengaruh Belanja Modal Pemerintah Daerah, Tenaga Kerja terserap dan Indeks Pembangunan Manusia terhadap Pertumbuhan Kkonomi dan Kemiskinan, Jurnal Bisnis Ekonomi (JBE) ISSN 1412-3126 Vol.20 no 2.Semarang: Universitas Diponegoro.

[32] Ram, R, (1986). Government Size and Economic Growth: a New Frame Work and some evidence from cross-section and time series data. American Economic Review, No. 76 : pp. 191-203.

[33] Safina, Lailan dan Rahayu, Sri Endang. (2011). Analisis Pengaruh Investasi Pemerintah dan Swasta Terhadap Penciptaan Kesempatan Kerja di Sumatera Utara. Jurnal Manajemen \& Bisnis. Volume 11, Nomor 01.

[34] Sala-I-Martin, Xavier X, (1997). I Just Run Two Million Regresion. AEA Paper and Proceding, Vol. 83, N. 2, May: pp.178-183.

[35] Sulistiawati. R, (2012). Pengaruh Investasi Terhadap Pertumbuhan Ekonomi dan Penyerapan Tenaga Kerja Serta Kesejahteraan Masyarakat di Provinsi di Indonesia. Fakultas Ekonomi Universitas Tanjungpura Pontianak. Jurnal Ekonomi Bisnis dan Kewirausahaan. 3(1). 29 - 50.

[36] Sjafrizal (1997). Pertumbuhan Ekonomi dan Ketimpangan Regional Wilayah Indonesia Bagian Barat, Jakarta, Jurnal Buletin Prisma.

[37] Todaro, Michael P. (2000). Pembangunan Ekonomi di Dunia Ketiga. Penerjemah: Haris Munandar. Erlangga: Jakarta.

[38] Todaro, Michael P. dan Stephen C. Smith. (2004). Pembangunan Ekonomi di Dunia Ketiga, Edisi kedelapan. Erlangga: Jakarta.

[39] Todaro, Michael P., and Smith, Stephen C., (2006). Pembangunan Ekonomi di Dunia Ketiga (Economic development in the Third World), 1st Edition, Jakarta: Erlangga.

[40] Undang -Undang Nomor. 32 Tahun (2004) tentang Pemerintahan Daerah. Jakarta. 
[41] Widjanarko, Bambang, (2009). Materi Pelatihan Structural Equation Modeling dan Partial Least Square (Teori). Diselenggarakan oleh Fakultas Kedokteran Hewan, Universitas Airlangga.

[42] Yasa, O. A. dan S. Arka. (2015). Pengaruh Pertum buhan Ekonomi dan Disparitas Penda patan Antardaerah Terhadap Kesejahteraan Masyarakat Provinsi Bali. E-Jurnal EP Unud, Vol 2, No. 2, hal. 129-136.

*Corresponding author.

E-mail address: samsul4rief@ gmail.com 